\title{
The Effects of Simulated Transportation on Plasma Levels of Catecholamines, Cortisol and Glucose and Eosinophil Count in the Goat
}

Tin Myo NWE, Emiko HORI, Yoshitaka NAKANISHI, Masaharu MANDA and Shozo WATANABE*

Faculty of Agriculture, Kagoshima University, Kagoshima-shi 890

* The Leasing Corporation for Livestock Industry's Environmental Improvement, Minato-ku, Tokyo 105

(Received September 5, 1994)

\begin{abstract}
The effects of simulated transportation on plasma levels of catecholamines, cortisol, glucose and number of eosinophils were studied in adult male Tokara goats. The swing model experiment (simulated transportation) composed of two types of movement; irregular and intense movements for $10 \mathrm{~min}$, and regular movement for $5 \mathrm{~min}$ and then these were repeated 6 times for $90 \mathrm{~min}$. Blood was obtained via indwelling catheters in jugular or femoral veins. During the swing movement, the behaviors apparently indicated nervousness or excitement. At 30 min from the beginning of the swing. plasma concentrations of epinephrine, norepinephrine, cortisol and glucose were all significantly elevated about 2 times of the base values, showing the peaks at the end of the swing movement except norepinephrine and they all returned to the base values after the termination of the swing movement. The number of eosinophils were started to decrease immediately after the beginning of the swing and showed the minimum level $1.5 \mathrm{~h}$ and then returned to the base value by $10.5 \mathrm{~h}$ after the termination of the swing movement. The present results clearly show that the swing movement activates the sympathetic nervous system and then both the adrenal medulla and cortex are simultaneously activated followed by immediate physiological changes such as glucose metabolism and the number of eosinophils. The results of the present study are in general agreement with those observed during the real transportation in our previous experiments. Thus, our swing model is thought to be able to simulate the real transportation stress.
\end{abstract}

Anim. Sci. Technol. (Jpn.) 66 (10) : 841-848, 1995

Key words : catecholamines, cortisol, glucose, goat, swing model

The hypothalamo-pituitary-adrenal axis is activated by stressors, resulting in increased concentrations of plasma cortisol and catecholamines ${ }^{10,22,24)}$. Cortisol and catecholamines are essential components of adaptation to stress. Catecholamines assist not only the progress of the stress response but also accelerates the cortisol actions. Epinephrine and norepinephrine secretions may be increased by transportation, and glycogenolysis and lipolysis are stimulated and thus meat composition may be changed in the stressed animals ${ }^{6,25)}$. It is also well known that stress affects the immune system of farm animals because immunity is reduced by both cortisol and catecholamines ${ }^{5.8 .14 .17}$.

Simulated transportation has been proposed to study the effects of physical and emotional 
stress of a real transportation by Locatelli et $a l .^{15\rangle}$ and Sartorelli et $a l^{20)}$. But, there were no reports comparing a simulated transportation with a real transportation. Thus, in the previous study, we devised a swing model as a simulated transportation and we compared it with a real transportation. In the previous stud $y^{199}$, it was shown that, the effect of transportation on plasma cortisol, glucose and the total number of white blood cell and eosinophils were quite similar to that of the swing model.

To establish the mechanism of the initiation of the transportation stress, determination of catecholamines is necessary, but no comprehensive analyses of the changes in plasma cortisol and catecholamines concentrations undergoing transportation or simulated transportation have been reported.

Thus, in the present study, a simulated transportation experiment was conducted to show the effect of transportation on plasma levels of catecholamines, cortisol, glucose and the number of eosinophils simultaneously.

\section{Materials and Methods}

The experiment was conducted in the period from October 1993 to March 1994.

\section{Animals :}

Three male adult Tokara goats, aged 1 to 3 years and approximately $25 \mathrm{~kg}$ body weight, were used in this study.

Housing and feeding :

The experimental animals were housed in wooden cages from 1 month prior to adapt for the new environment and were fed a mixture of beet pulp and hay cube, formula feed and barley twice daily at $8: 30 \mathrm{~h}$ and $16: 00 \mathrm{~h}$ as reported previously ${ }^{19}$.

\section{Catheterization :}

To minimize stress resulting from frequent venipuncture and animal manipulation, blood was withdrawn from an indwelling jugular vein catheter. The catheter was inserted into a left jugular vein by surgical operation as reported previously ${ }^{19}$. After the catheterization, the goats were allowed to recover from surgical trauma for at least 5 days before the start of the experiment. To prevent clogging the both catheters were flushed twice daily with sterile saline containing $10,000 \mathrm{IU}$ unit heparin per $\mathrm{m} l$.

\section{Swing model experiment :}

The procedure for the swing model experiment has described in the previous paper ${ }^{19)}$. The swing schedule consisted of the $15 \mathrm{~min}$ module of two types of movement as summarized in Table 1. Where, velocity (V) of swing at horizontal position, for example, is $\sqrt{2 g h}$, here " $h$ " is the maximum height of vertical swing movement $(50 \mathrm{~cm})$ and $g$ the gravity $\left(981 \mathrm{~cm} / \mathrm{sec}^{2}\right)$, therefore $\mathrm{V}=313 \mathrm{~cm} / \mathrm{sec}$. The $15 \mathrm{~min}$ swing schedule was 20 cycles/min and inclination angle was $45^{\circ}$ and repeated 6 times during $90 \mathrm{~min}$ of the swing movement. The swing experiment was started at $9: 00 \mathrm{~h}$ and the blood sample was taken at $8: 00 \mathrm{~h}$ before the start of the swing experiment. During the swing experiment blood samples were taken at $30,60,90 \mathrm{~min}$ and then continued at $3 \mathrm{~h}$ intervals for $12 \mathrm{~h}$ and the next $6 \mathrm{~h}$ intervals for $24 \mathrm{~h}$ after the start of the swing movement.

Ten $\mathrm{m} l$ of blood was withdrawn each time and immediately cooled in an ice container.

Table 1. The time schedule of the swing treatment

\begin{tabular}{|c|c|c|c|c|c|c|c|c|c|c|c|}
\hline & 0 & 10 & 20 & 30 & 40 & 50 & 60 & 70 & 80 & 90 & $\min$ \\
\hline $\begin{array}{l}\text { Irregular and } \\
\text { intense movement }\end{array}$ & 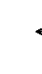 & & $\longleftrightarrow$ & & & $\longleftarrow$ & & $\rightarrow$ & $\longleftarrow$ & & \\
\hline Regular movement & & $\leftrightarrow$ & & $\leftrightarrow$ & $\leftrightarrow$ & & $\leftrightarrow$ & $\leftrightarrow$ & & $\leftrightarrow$ & \\
\hline
\end{tabular}

The swing schedule composed of two types of movement; irregular and intense movements for $10 \mathrm{~min}$, and regular movement for $5 \mathrm{~min}$ and then these were repeated 6 times $(\leftrightarrow)$ for $90 \mathrm{~min}$. 
Before centrifugation, a $1 \mathrm{~m} l$ aliquot was taken for hematological counting and $9 \mathrm{~m} l$ of the heparinized blood was centrifuged at 2,500 rpm $\left(1,300 \times \mathrm{g}, 20^{\circ} \mathrm{C}\right)$ for $10 \mathrm{~min}$. The plasma was stored at $-70^{\circ} \mathrm{C}$ until assayed. The number of eosinophils was counted using a standard hemocy tometer. The concentration of plasma glucose was determined by Spectrophotometer RaBA-ACE with Unikit reagents (Chugai, Daiichi, Kyoto, Japan).

The plasma levels of epinephrine $(E)$ and norepinephrine (NE) were determined by highperformance liquid chromatography with fluorescence detection ${ }^{16)}$. After cation-exchange chromatography on a Toyopak SP cartridge, the catecholamines and isoproterenol (internal standard) in $500 \mu l$ of plasma are converted into the corresponding fluorescent compounds by reaction with 1,2-diphenylethylenediamine in aqueous acetonitrile. These compounds are separated within 8 min on a reversed-phase column, TSK-gel ODS-120 T, with isocratic elution using a mixture of water, methanol and acetonitrile containing a Tris-hydrochloric buffer ( $\mathrm{pH}$ 7.0). The amounts of catecholamines were calculated based on the internal standard method. Isoproterenol was used as an internal standard.

Plasma cortisol concentration was measured by the method of Scott and Dixon ${ }^{23)}$ using HPLC as described in the previous paper ${ }^{19}$.

Statistical analysis :
The data were subjected to analyses of variance (ANOVA), and the difference of means was tested by Student " $t$ " test.

\section{Results}

The behaviors observed during the experiment are summarized in Table 2. The behaviors apparently indicated nervousness or excitement.

Plasma levels of $E$ were increased significantly $(\mathrm{P}<0.05) 30 \mathrm{~min}$ of the start (Fig. $1 \mathrm{a})$ which was 2 times higher than that before the swing treatment. The highest value was observed at the end of the swing $(\mathrm{P}<0.05)$ and then returned to the base value by $9 \mathrm{~h}$ after the start of the swing movement. The plasma levels of $\mathrm{NE}$ were increased significantly ( $\mathrm{P}<$ $0.05) 30$ min of the start (Fig. 1 b) which was 2 times higher than that before the swing treatment. The highest value was observed $4.5 \mathrm{~h}(\mathrm{P}$ $<0.05)$ and then returned to the base value 7.5 $\mathrm{h}$ after the termination of the swing movement. Both plasma levels of $\mathrm{E}$ and $\mathrm{NE}$ were increased $4.5 \mathrm{~h}$ after the termination of the swing movement.

Plasma cortisol concentration was significantly $(\mathrm{P}<0.05)$ increased within $30 \mathrm{~min}$ of the start (Fig. 2 a). The peak value was observed at the end of the swing which was on the average four times higher than that before the start and the elevated value was maintained throughout the swing movement. Immediate-

Table 2. The behaviors observed during the model swing treatment

\begin{tabular}{l}
\hline Behaviors observed \\
Kneeling down \\
(Supporting the body with the knee of the forelegs and feet of extended hindlegs) \\
Sniffing and Flehmen \\
(Gesture directing the nose within $10 \mathrm{~cm}$ of a surface and/or object) \\
Trembling \\
(Shake involuntarily from emotion, weakness) \\
Scrambling or Struggling \\
(Try to keep their balance and to restore their disturbed postures) \\
Laying down \\
Salivation
\end{tabular}


ly after the end of the swing, cortisol concentration started to decline and returned to the base value $1.5 \mathrm{~h}$ after the termination of the swing. Plasma glucose significantly increased $(\mathrm{P}<0.01)$ within $30 \mathrm{~min}$ after the beginning (Fig. $2 \mathrm{~b}$ ) and the peak value was observed at the end of the swing, that level was 3 times higher than that before the swing value. The elevated value was maintained throughout the swing movement and then returned to the base value $4.5 \mathrm{~h}$ after the termination of the swing. The number of eosinophils started to decrease within $30 \mathrm{~min}(\mathrm{P}<0.05)$ and reached the minimum level at $3 \mathrm{~h}$ from the start, that level showed 2.5 times lower than that before the swing $(\mathrm{P}<0.05)$. And then eosinophil level returned to the base value $10.5 \mathrm{~h}$ after the ter-
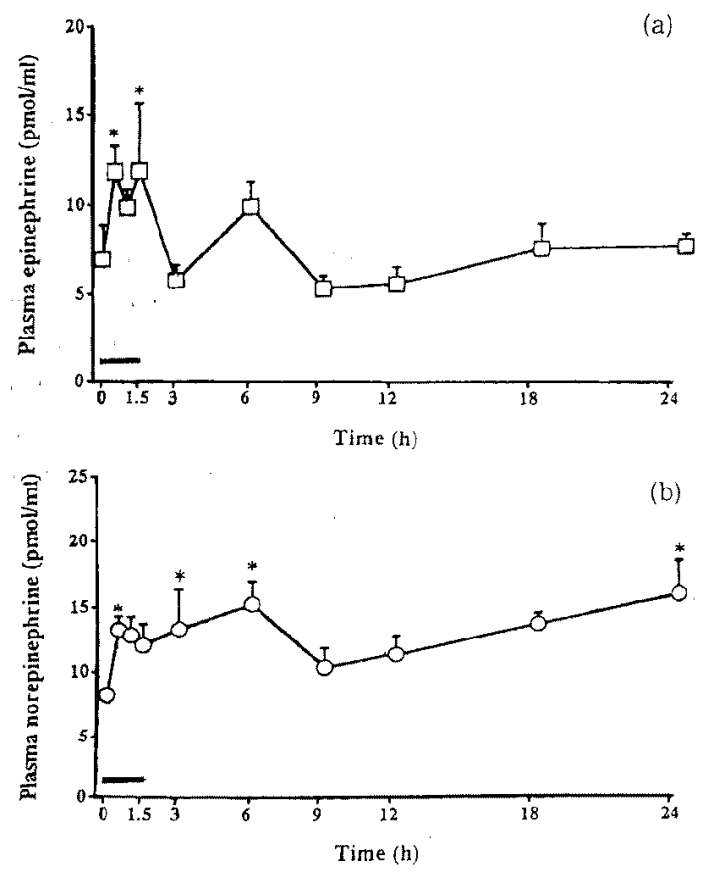

Fig. 1. (a) Plasma levels of epinephrine ( $\square$ ) and (b) norepinephrine (O) before, during and after swing treatment in the goat. Values are means $\pm \mathrm{SE} ; \mathrm{n}=3$. Bold line in the figure shows period of the swing movement. ${ }^{*} \mathrm{P}<0.05$ compared with the value before start. mination of the swing (Fig. 2c).

\section{Discussion}

In the stressful conditions, catecholamines were released from adrenal medulla and nerve endings and present in the blood. Epinephrine and norepinephrine are produced and stored in different cells in the adrenal medulla and other chromaffin cells. Collections of

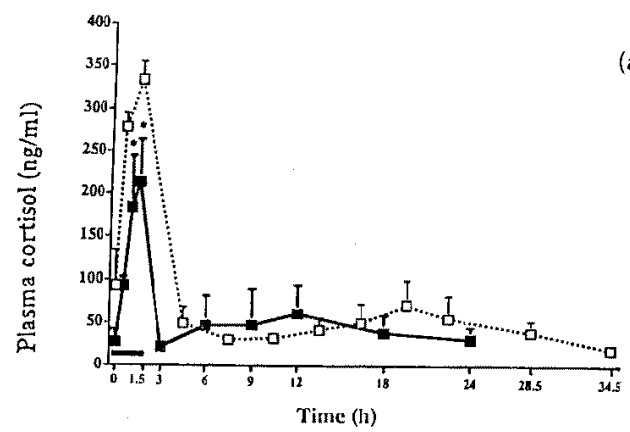

(a)
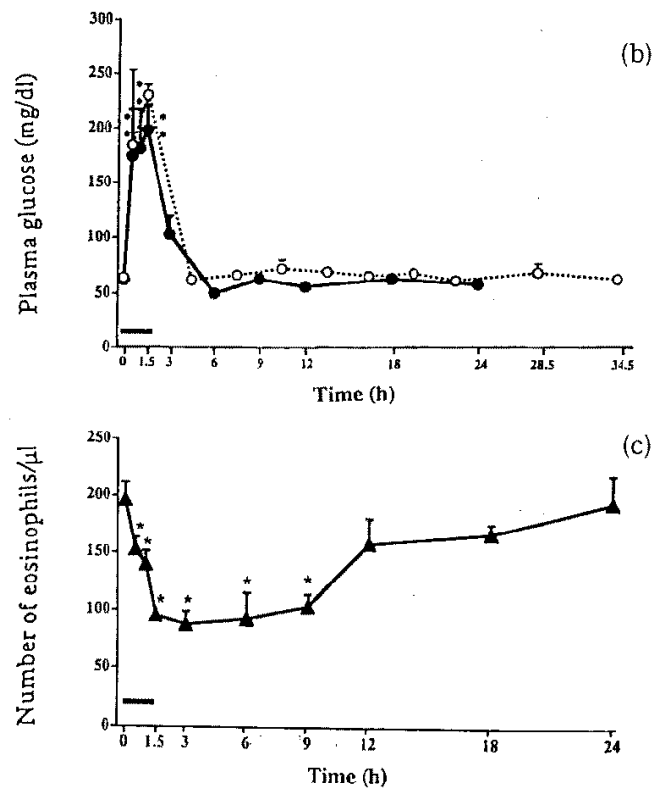

Fig. 2. (a) Plasma levels of cortisol ( $\mathbf{a}$ ), (b) glucose (O) and (c) the number of eosinophils (A) before, during and after swing treatment in the goat. Values are means $\mathrm{SE} ; \mathrm{n}=3$. Bold line in figure shows period of the swing movement. ${ }^{*} \mathrm{P}<0.05 ;{ }^{* *} \mathrm{P}<0.01$ compared with the value before start. Dotted line (.....) in Fig. 2. (a) and (b) shows the concentrations of previous paper ${ }^{25)}$. 
these cells are also found in the heart, liver, kidney, gonads, adrenergic neurons of the postganglionic sympathetic system, and central nervous system. Most of norepinephrine present in these organs innervated by sympathetic nerve is made in situ ( $\sim 80 \%$ of the total) and most of the rest is made in other nerve endings and reaches the target sites via the circulation $^{18)}$. These are quickly removed from plasma so that blood levels fluctuate rapidly, reflecting the degree of sympathetic neuronal activity ${ }^{4)}$. The present paper is the first reporting the time course changes in plasma catecholamines concentrations in goats during a simulated transportation.

In earlier studies on transportation stress, blood sampling for hormone assay was performed only before and after the transportation and thus, the time course changes of plasma hormones were not reported which is very important to show the stress response ${ }^{2)}$. The changes in plasma levels of $\mathrm{E}$ and $\mathrm{NE}$ observed in this study provide evidence for fluctuations in activity of the sympathetic-adrenal medulla axis during the swing treatment. Plasma E levels increased significantly at 30 min after the beginning of the swing movement and the level was two-fold higher than the base value. Plasma NE levels significantly increased as the same timing as $\mathrm{E}$ but not so high. After the termination of the swing movement, plasma $\mathrm{E}$ levels returned to the base value, but plasma NE levels did not decline. Itoh ${ }^{11}$ has reported that the concentration of plasma NE showed the high levels and these levels were maintained up to the 60 days when exposed to the cold environment, although plasma $E$ level once increased and decreased quickly after the exposure. The increased levels of plasma NE after the termination of the swing movement may be connected with increased muscle activity ${ }^{1)}$. The animal was very nervous and restless during the swing movement and after the termination of the swing, the animal was taking a rest and after this the animal became active again (eating and moving).

Plasma concentrations of cortisol and glucose were significantly increased after the beginnings of the swing movement. The maintenance of glucose in the blood is one of the most finely regulated of homeostatic mechanisms in which the liver, the extrahepatic tissues, and several hormones play a part. The glucocorticoids are secreted by the adrenal cortex and have an important role in carbohydrate metabolism. Administration of these steroids causes increased gluconeogenesis. This is a results of increased protein catabolism in the tissues, increased hepatic uptake of amino acids, and increased activity of transaminases and other enzymes concerned with gluconeogenesis in the liver. In the stressful conditions, plasma glucocorticoids are increased and glucose synthesis is accelerated ${ }^{12,13)}$. At the same time, catecholamines were secreted from the sympathetic nerve endings and adrenal medulla as a results of stressful stimuli and induced excessive glycogenolysis in liver and muscle owing to a stimulation of phosphorylase. In muscle, as a result of the absence of glucose-6-phosphatase, glycogenolysis ensues with the formation of lactate, whereas in liver, glucose is the main product leading to an increase in blood glucose which is regarded as being fundamental to increase plasma glucose concentrations ${ }^{18)}$.

The decreased number of eosinophil was also observed during the swing movement. It is well known that eosinopenia is induced by physical and emotional stress and this is thought to be attributed to the elevated levels of plasma cortisol. In fact, it has been reported that continuous release of corticosteriods or prolonged steroid therapy causes decreased production of eosinophils ${ }^{3)}$. It is also known that cytokines are important mediators of the response of the haematopoietic system to stress. Cytokines released during stress not only increase blood cell production 
but also modulate the types of cells produced. The stress responses thus involves not only acceleration of the normal mechanisms of haematopoiesis but also overriding of some types that are produced ${ }^{21)}$. The present results suggest that transportation stress affects immunity of the animals in addition to plasma concentrations of catecholamines, cortisol, glucose and so on.

The present results also clearly show that the swing movement activates the sympathetic nervous system and then both the adrenal medulla and cortex were simultaneously activated followed by immediate physiological changes such as glucose metabolism and the number of eosinophils. The results of the present study are in general agreement with those observed during the real transportation in our previous experiments. Thus, our swing model is thought to be able to simulate the real transportation stress.

\section{Acknowledgements}

The authors are grateful to Professor Ryosuke Shimizu and all surgeons, Laboratory of Veterinary Surgery, Kagoshima University, for their skillful catheterization. We would also like to express our gratitude to Associate Professor Kunioki Hayashi, for his guidance and invaluable technical advice and to Assistant Professor Akira Ohtsuka, for his supervision on the technique of liquid chromatography, Laboratory of Nutritional Biochemistry and Feed Science, Faculty of Agriculture, Kagoshima University.

\section{References}

1) Akerstedt $T$, Gillberg $M$, Hjemdahl $P$, Sigurdson K, Gustavsson I, Daleskog M, Pollare T. Comparison of urinary and plasma catecholamine response to mental stress. Acta Physiol. Scand., 117 : 19-26. 1983.

2) Becker BA, Nienaber JA, Deshazer JA, Hahn GL. Effect of transportation on cortisol concentrations and on the circadian rhythm of cortisol in gilts. Amer. J. Vet. Res., $46: 1457-$
1459. 1985

3) Beeson PB, Bass DA. The Eosinophil. In Major Problems in Internal Medicine. (Smith LH Jr. ed.) Vol. 14. W. B. Saunders. Philadelphia. 1977.

4) Charles RL, Michael GZ, Irwin JK. Use of plasma norepinephrine for evaluation of sympathetic neuronal function in man. Life Sci., $18: 1315-1326.1976$.

5) Crary B. Borysenko M, Sutherland DC, Kutz I, Borysenko JZ, Benson H. Decrease in mitogen responsiveness of mononuclear cells from peripheral blood after epinephrine administration in humans. J. Immunol., $130: 694-697.1983$.

6) Dantzer R, Mormede P. Stress in farm animals : A need for reevaluation. J. Anim. Sci., $57: 6-18.1983$.

7) Dalin AM, Magnusson U, Haggendal J, Nyberg L. The effect of transport stress on plasma levels of catecholamines, cortisol, coticosteriod-binding globulin, blood cell count, and lymphocyte proliferation in pigs. Acta vet. scand., $34: 59-68.1993$.

8) Fauci AS. Immunosuppressive and antiinflammatory effects of glucocorticoids. Monograph. Endocrinol., 12 : 449-465. 1979.

9) Freeman BM. Stress and the Domestic Fowl: Physiological Fact or Fantasy? World's Poultry Sci., 41: 45-51. 1985.

10) Heny JP, Stephens PM. Stress, health and social environment. A sociobiologic approach to medicine. Topics in environmental physiology and medicine. Springer-Verlag. Berlin. 1977.

11) Itoh S. Hormones. Scientific American (Japanese edition), $37: 204-217.1986$.

12) Kent JK, Ewbank R. The effect of road transportation on the blood constituents and behavior of calves. I. Six month old. Br. Vet. J., 139 : 228-235. 1983.

13) Kent JK, Ewbank R. The effect of road transportation on the blood constituents and behayior of calves. II. One to three weeks old. Br. Vet. J., 142 : 131-140. 1986.

14) Landmann RMA, Miller FB, Perini CH, Wesp $M$, Erne P, Buhler FR. Changes of immunoregulary cells induced by psychological and physical stress : relation to plasma catecholamines. Clin. Exp. Immunol., $58: 127-135$. 1981.

15) Locatelli A, Sartorelli P, Agnes F, Bondiolotti GP, Picotti GB. Adrenal response in the calf to repeated simulate transport. Br. Vet. J., 145: 517-522. 1989. 


\section{Simulated Transportation in Goat}

16) Mitsui A, Nohta H, Okura Y. High-performance liquid chromatography of plasma catecholamines using 1, 2-diphenyl-ethylenediamine as precolumn fluorescence derivatization reagent. J. Chromatogr., 344 : 61-70. 1985 .

17) Munck AP, Guyre P, Holbrook N. Physiological functions of glucocorticoids in stress and their relation to pharmacological actions. Endocr. Rev., 5 : 25. 1984

18) Murray RK, Granner DK, Mayes PA, Rodwell VW. Gluconeogenesis and control of the blood glucose ; Hormones of the adrenal cortex and adrenal medulla. Harper's Biochemistry. 12 th ed. 186-187, 499-515. Prentice-Hall International Inc. 1990

19) Nwe TM, Tsukahara $Y$, Manda $M$, Watanabe $S$. Initiation of the simulate and real transporta. tion stress in the goat. Anim. Sci. Technol. (Jpn.), $65: 1008-1017.1994$.

20) Sartorelli $P$, Dominoni S, Agnes F. Influence of duration of simulated transport on plasma stress markers in the calf. J. Vet. Med., A 39 :
401-403. 1992.

21) Schrader JW. Interleukin-3. The Cytokine Hand book. (Thomsom AW ed.) 103-118. Academic Press. London and New york Inc. 1991.

22) Sconberg $\mathrm{S}$, Nockels $\mathrm{CF}$, Bennet $\mathrm{BW}$ Bruyninckx W, Blancouaert Anne-Marie B Craig AM. Effects of shipping, handling, adrenocorticotropic hormone, and epinephrine on $\alpha$-tocopherol content of bovine blood. Am. J. Vet. Res., $54:$ 1287-1293. 1993.

23) Scott NR, Dixon PF. Determination of cortisol in human plasma by reversed phase high performance liquid chromatography. J. Chromatogr., $164: 29-34.1979$

24) Stephens DB. Stress and its measurement in domestic animals : a review of behavioral and psychological studies under field and laboratory situations. Adv. Vet. Sci. Comp. Med., 24 179-210. 1980.

25) Tarrant PV, Sherington J. An investigation of ultimate $\mathrm{pH}$ in the muscles of commercial beef carcasses. Meat Sci., $4: 287-297.1980$. 


\title{
ヤギにおける輸送シミュレーション負荷が血中カテコールアミン， コルチゾール，グルコース濃度および好酸球数に及ぼす影響 \\ ディンミョウヌエ・堀 英美子・中西良孝・萬田正治・渡邊昭三* \\ 鹿児島大学農学部, 鹿児島市 890 \\ *畜産環境整備リース協会, 東京都港区 105
}

\begin{abstract}
成雄トカラヤギを供試して輸送シミュレーション負荷後の血中カテコールアミン，コルチゾール，グ ルコースおよび好酸球数の变動を明らかにした．ブランコ振動による輸送シミュレーションでは，ケー ジに入れたまま不規則な振動と規則的な振動を組み合わせた 1 セッ15 分間の負荷を6回繰り返した

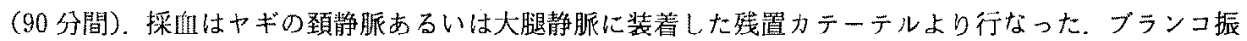

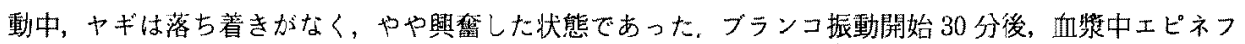
リン, ノルエピネフリン, コルチゾールおよびグルコース濃度は振動開始前の値の 2 倍に上昇し，ノル エピネフリンを除きそれらの值はブランコ振動終了時にピークを示したが，その後は次第に低下する傾 问をホし，振動開始前の值に戻った，好酸球数はブランコ振動開始直後に減少し，浱動終了 1 時間半後 に最小值を示したが, 振動終〕 10 時間半後には振動開始前の值に戻った. 本研究の結果は, 翰送シミュ レーション負荷が父感神経系を刺激するとともに，副腎皮質扰よで䯣質を同時に賦活化し，糖質代謝や 免疫機能などの生理的変化をあたらすことを示している．また，上述の生理諸元の变動は実際の輸送実 験の絬果と定性的に一致しており，ブランコ振動が輸送モデルとなり得る㫗のと考えられる。
\end{abstract}

日畜会報，66 (10): $841-848,1995$ 